\title{
PENGUKURAN KINERJA PERUSAHAAN DENGAN MENGGUNAKAN METODE PER- FORMANCE PRISM PADA PT TUNAS DWIPA MATRA
}

Oleh:

Anisa Tri Bintarti

08412141049

\begin{abstract}
ABSTRAK
Penelitian ini bertujuan untuk mengetahui kinerja PT Tunas Dwipa Matra yang diukur dengan metode Performance Prism pada periode Januari sampai dengan Juli 2012. Pengukuran kinerja dengan metode Performance Prism ini terdiri dari lima perspektif, yaitu stakeholder satisfaction (kepuasan stakeholder), stakeholder contribution (kontribusi stakeholder), strategy (strategi), process (proses), dan capability (kapabilitas).

Penelitian ini merupakan penelitian deskriptif baik kualitatif maupun kuantitatif. Subjek yang diteliti dalam penelitian ini adalah seluruh stakeholder yang terlibat dalam PT Tunas Dwipa Matra yang terdiri dari manajemen, karyawan, pemasok, pelanggan, mitra, dan pemerintah. Objek dalam penelitian ini adalah aktivitas kinerja pada PT Tunas Dwipa Matra yang diukur dengan metode Performance Prism pada periode Januari sampai dengan Juli 2012. Penelitian ini menggunakan metode AHP (Analytical Hierarchy Process) yang dianalisis dengan bantuan metode OMAX (Objective Matrix) dan Traffic Light System.

Matra jika diukur dari indikator Stakeholder Satisfaction menunjukkan hasil empat KPI berada pada kategori hijau, dua KPI berada pada kategori kuning, satu KPI berada pada kategori merah. (2) Kinerja PT Tunas Dwipa Matra jika diukur dari indikator Stakeholder Contribution menunjukkan hasil dua KPI berada pada kategori hijau, satu KPI berada pada kategori kuning, dan lima KPI berada pada kategori merah. (3) Kinerja PT Tunas Dwipa Matra jika diukur dari indikator Strategy menunjukkan hasil Dua KPI berada pada kategori hijau, dua KPI berada pada kategori kuning, dan satu KPI berada pada kategori merah. (4) Kinerja PT Tunas Dwipa Matra jika diukur dari indikator Process menunjukkan hasil tiga KPI berada pada kategori hijau, dua KPI berada pada kategori kuning, tidak ada KPI pada indikator Process yang berada pada kategori merah. (5) Kinerja PT Tunas Dwipa Matra jika diukur dari indikator Capability menunjukkan hasil dua KPI berada pada kategori hijau, tidak ada KPI yang berada pada kategori kuning, tiga KPI berada pada kategori merah.
\end{abstract}

Hasil penelitian ini menunjukkan bahwa kinerja PT Tunas Dwipa Matra terukur dari 31 KPI (Key Performance Indicators). Pengukuran kinerja yang dilakukan menghasilkan (1) Kinerja PT Tunas Dwipa
Kata kunci: performance prism, AHP, KPI 


\section{Jurnal Nominal / Volume I Nomor I / Tahun 2012}

\section{A. PENDAHULUAN}

Performance Prism merupakan sebuah teori yang dikembangkan oleh Universitas Cranfield, kemudian pada tahun 2000 Neely, Adams, dan Kennerley mencoba memperkenalkannya sebagai sebuah metode pengukuran kinerja perusahaan. Metode ini mencoba memperbaiki kekurangankekurangan yang ada pada metode- metode sebelumnya seperti Balanced Scorecard. Kelebihan metode ini dibanding dengan metode-metode sebelumnya adalah bahwa Performance Prism mencoba mempertimbangkan seluruh stakeholder dari perusahaan seperti investor, pelanggan, karyawan, Peraturan Pemerintah sebagai bagian yang saling terintegrasi. Dengan kata lain pengukuran kinerja yang dilakukan tidak hanya terbatas pada beberapa stakeholder saja seperti yang dilakukan pada pengukuran kinerja pada metode terdahulu.

\section{B. PEMBAHASAN}

Hasil pengukuran kinerja perusahaan menggunakan metode Performance Prism terdiri dari beberapa hal sebagai berikut.

1. Kinerja PT Tunas Dwipa Matra jika diukur dari indikator Stakeholder Satisfaction menunjukkan hasil sebagai berikut:

a. Empat KPI berada pada kategori hijau atau telah berhasil mencapai target maksimal yang telah ditentukan.

b. Dua KPI berada pada kategori kuning atau telah mencapai target yang ditetapkan namun belum dapat mencapai nilai yang maksimal.

c. Satu KPI berada pada kategori merah atau belum mencapai target yang ditentukan.

2. Kinerja PT Tunas Dwipa Matra jika diukur dari indikator Stakeholder Contribution menunjukkan hasil sebagai berikut:

a. Dua KPI berada pada kategori hijau atau telah berhasil mencapai target maksimal yang telah ditentukan.

b. Satu KPI berada pada kategori kuning atau telah mencapai target yang ditetapkan namun belum dapat mencapai nilai yang maksimal.

c. Lima KPI berada pada kategori merah atau belum mencapai target yang ditentukan.

3. Kinerja PT Tunas Dwipa Matra jika diukur dari indikator Strategy menunjukkan hasil sebagai berikut:

a. Dua KPI berada pada kategori hijau atau telah berhasil mencapai target maksimal yang telah ditentukan.

b. Dua KPI berada pada kategori kuning atau telah mencapai target yang ditetapkan namun belum dapat mencapai nilai yang maksimal.

c. Satu KPI berada pada kategori merah atau belum mencapai target yang ditentukan.

4. Kinerja PT Tunas Dwipa Matra jika diukur dari indikator Process menunjukkan hasil sebagai berikut:

a. Tiga KPI berada pada kategori hijau atau telah berhasil mencapai target maksimal yang telah ditentukan.

b. Dua KPI berada pada kategori kuning atau telah mencapai target yang ditetapkan namun belum dapat mencapai nilai yang maksimal.

c. Tidak ada KPI pada indikator Process yang be- 
rada pada kategori merah, yang menunjukkan bahwa pada indikator ini kinerja PT Tunas Dwipa Matra telah mencapai target yang ditentukan.

5. Kinerja PT Tunas Dwipa Matra jika diukur dari indikator Capability menunjukkan hasil sebagai berikut:

a. Dua KPI berada pada kategori hijau atau telah berhasil mencapai target maksimal yang telah ditentukan.

b. Tidak ada KPI yang berada pada kategori kuning atau telah mencapai target yang ditetapkan namun belum dapat mencapai nilai yang maksimal.

c. Tiga KPI berada pada kategori merah atau belum mencapai target yang ditentukan.

\section{PENUTUP}

Berdasarkan hasil pengukurankinerja dengan menggunakan metode Performance Prism dapat disimpulkan sebagai berikut:

1. Tiga belas KPI berada pada kategori hijau, yang menunjukkan kinerjanya sudah melampaui target yang ditetapkan dan perlu dipertahankan.

2. Tujuh KPI berada pada kategori kuning, yang menunjukkan kinerjanya sudah memenuhi target yang ditetapkan dan perlu ditingkatkan.

3. Sepuluh KPI berada pada kategori merah, yang menunjukkan kinerjanya masih jauh dari target dan perlu diperbaiki.

\section{DAFTAR PUSTAKA}

Moeheriono. (2012). Perencanaan, Aplikasi dan Pengembangan Indikator Kinerja Utama (IKU) Bisnis dan Publik. Jakarta: Rajawali Pers.

Mulyadi. (2007). Sistem Perencanaan dan Pengendalian Manajemen: Sistem Pelipatganda Kinerja Perusahaan. Jakarta: Salemba Empat.

Neely, A., Adams, C., \& Kennerley, M. (2002). The Performance Prism: The Scorecard for Measuring and Managing Business Success. London: Prentice Hall.

Pande, Peter S., Robert, P. Neuman., \& Roland, R. Cavanagh. (2000). The Six Sigma Way: Bagaimana GE, Motorola, dan Perusahaan Terkenal Lainnya Mengasah Kinerja Mereka. Yogyakarta: Penerbit Andi.

Saaty, Thomas L., \& Vargas, Luis G. (2006). Decision Making with The Analytical Network Process: Economic, Political, Social, and Technological Application with Benefit, Opportunities, Cost and Risks. Pittsburgh: Springer.

Sandy Kosasi. (2002). Sistem Penunjang Keputusan (Decision Support System): Konsep dan Rerangka Pemodelan Sistem Penunjang Keputusan Berbasis Teknologi Informasi. Diktat. Sekolah Tinggi Manajemen Informatika dan Komputer.

Veithzal Rivai. et al. (2008). Performance Appraisal: Sistem yang Tepat untuk Menilai Kinerja Karyawan dan Meningkatkan Daya Saing Perusahaan. Jakarta: Rajawali Pers. 